\title{
Cytomegalovirus-induced immunopathology and its clinical consequences
}

\author{
Stefania Varani* and Maria Paola Landini
}

\begin{abstract}
Human cytomegalovirus (CMV) is a ubiquitous DNA virus that causes severe disease in patients with immature or impaired immune systems. During active infection, CMV modulates host immunity, and CMV-infected patients often develop signs of immune dysfunction, such as immunosuppression and autoimmune phenomena. Furthermore, active viral infection has been observed in several autoimmune diseases, and case reports have linked primary CMV infection and the onset of autoimmune disorders. In addition, CMV infection promotes allograft rejection and graft-versus-host disease in solid organ and bone marrow transplant recipients, respectively, further implicating CMV in the genesis and maintenance of immunopathological phenomena. The mechanisms by which CMV could induce inhibition of host defense, inflammation, and autoimmunity are discussed, as is the treatment of virus-induced immunopathology with antivirals.
\end{abstract}

\section{Human cytomegalovirus}

Human cytomegalovirus (CMV) is a widespread agent that belongs to the Herpesviridae family [1]. Viral proteins are expressed in the immediate early (IE), early (E), and late (L) phases of CMV infection. Its genome contains more than 200 potential reading frames from which effector proteins can be generated, but merely one-quarter is committed to replication $[2,3]$. Thus, the majority of viral proteins potentially modulates cellular responses in the host; of all herpesviruses, CMV expresses the most genes that alter innate and adaptive host immune responses [4].

During the acute phase of CMV infection, many cell types in an organ system can be infected, including endothelial cells, epithelial cells, smooth muscle cells, fibroblasts, neuronal cells, hepatocytes, trophoblasts, monocytes/macrophages (M $\varphi s$ ), and dendritic cells (DCs) [5]. The virus typically is acquired early in life and can be transmitted by direct or indirect contact with infected body fluids. There are 3 forms of active CMV infection: a) primary infection, which occurs when the virus infects a CMV-naive host; b) endogenous infection in CMV-seropositive individuals who experience reactivation from latency, and c) exogenous

\footnotetext{
* Correspondence: stefania.varani@unibo.it

Section of Microbiology, Department of Hematology and Oncology,
} University of Bologna, Bologna, Italy

reinfection in previously infected individuals who experience infection by a different strain [6].

Recent evidence shows that active and latent CMV infection induces sustained systemic inflammatory responses that are accompanied by a type 1 cytokine signature [7]. Viral persistence is established in all infected individuals and is chronically productive or occurs as a latent infection in which viral gene expression is limited [8].

Initiation of viral replication from latency not only is caused by immunosuppression but, like other viruses, such as HIV [9], also appears to be linked to activation of the immune system. For example, the virus can be reactivated by tumor necrosis factor (TNF)- $\alpha$, which is released during inflammation. TNF- $\alpha$ binds to the TNF receptor on latently infected cells, generating signals that activate nuclear factor-kB (NF-kB). Consequently, the activated p65/p50 NF-kB heterodimer translocates into the nucleus and binds to the IE enhancer region of CMV, which initiates viral replication [10].

This molecular mechanism has a clinical correlate, wherein the reactivation of latent CMV has been associated with elevated serum levels of TNF- $\alpha$ in patients with atopic dermatitis [11] and sepsis [10,12,13]. In addition, CMV reactivates commonly following acute rejection of organ transplants and after acute graft-versus-host disease (GVHD) in bone marrow transplant 
(BMT) recipients who have elevated TNF- $\alpha$ levels [14-17].

Further, proinflammatory prostaglandins stimulate cyclic AMP, which then triggers viral reactivation [18]. Stress catecholamines can induce increases in cyclic AMP concentrations, leading to viral reactivation $[6,19]$. Through such mechanisms, chronic inflammation is likely to mediate the reactivation of CMV.

Cells of the myeloid lineage are carriers of latent CMV $[20,21]$. CMV can reactivate from latency by allogeneic stimulation of monocytes from seropositive donors [22]. Viral reactivation also occurs when mononuclear hematopoietic progenitors that are latently infected with CMV differentiate into mature DCs [23]. Thus, inflammation and cellular differentiation are events that reactivate $\mathrm{CMV}$.

\section{Clinical features of CMV infection and disease CMV infection in immunocompetent hosts}

In adults, primary CMV infection occurs in $0.1 \%$ to $0.6 \%$ of blood donors and typically is prolonged [24,25]. Immunocompetent individuals with primary infections are frequently asymptomatic $[25,26]$, but CMV occasionally effects clinical illness-i.e., a self-limited mononucleosis-like syndrome. Clinically, the mononucleosis that is caused by CMV is similar to the more common Epstein-Barr virus (EBV) mononucleosis. Malaise, headache, and high fever are hallmarks of CMV mononucleosis and can persist for weeks. Other clinical abnormalities have been associated with CMV infection in normal hosts, including Guillain-Barré syndrome, meningoencephalitis, hemolytic anemia, and thrombocytopenia [1].

\section{CMV infection in immunocompromised patients}

CMV infections are among the most common infections that follow transplantation. In such transplant recipients, CMV infection manifests as a wide range of conditions, from asymptomatic viremia to CMV syndrome and tissue-invasive disease [27].

CMV infection in immunocompromised individuals causes disparate clinical syndromes in different groups of patients, and the severity of infection is proportional to the degree of immunosuppression. The most severe infections develop in allogeneic bone marrow and allogeneic stem cell transplant (alloSCT) recipients and in AIDS patients with low $\mathrm{CD}^{+}{ }^{+}$counts. Symptomatic CMV infections are also observed often in solid organ transplant recipients.

The effects of CMV infection in transplant patients can be divided into 2 categories: direct effects of the infection that cause mononucleosis-like syndrome or tissue-invasive disease, and indirect effects [28-30]. CMV tissue-invasive disease is suspected if high levels of
CMV viremia develop and is confirmed by detection of the virus in the affected tissue by immunohistochemistry. The transplanted organ is the principal target of CMV infection in solid organ recipients [30]. This is not the case in BMT recipients, where CMV disease frequently manifests as interstitial pneumonia [31].

CMV is also associated with indirect effects, a term that encompasses the effects that are coupled to longer periods of low viral replication and that are caused in part by the host's immune response. Such effects include graft rejection and immunosuppression.

\section{CMV infection in patients with autoimmune disorders}

Recently, laboratory-based signs of active CMV infection have been observed in association with the onset and course of autoimmune diseases, as reviewed extensively below.

\section{The virus as an immunopathological agent: autoimmunity, immunosuppression, and graft rejection}

\section{A. Autoimmunity \\ A1. Induction of autoantibodies}

Autoimmune phenomena often develop in CMVinfected patients. For example, anti-phospholipid and anti-CD13 autoantibodies have been observed in CMVinfected BMT recipients [32-34], and anti-CD13 has been linked to the development of chronic GVHD in these patients [35]. In solid organ transplant recipients, non-organ-specific autoantibodies, such as anti-endothelial cell, anti-smooth muscle cell, and anti-nucleus antibodies, are associated with CMV infection [36,37], likely increasing the risk for humoral and chronic allograft rejection [38,39]. In addition, hypergammaglobulinemia, cryoglobulinemia, and autoantibody production are features of $\mathrm{CMV}$-induced mononucleosis and postperfusion syndrome [40-42].

\section{A2. Induction of vasculitides and scleroderma}

The time course of active CMV infection and the onset of autoimmune disorders have been linked in previously healthy individuals. Notably, the presence of CMV replication has been associated with the development of autoimmune vasculitis and scleroderma, implicating virus-induced vasculopathy as a trigger of autoimmunity.

In fact, active CMV infection has been correlated with newly diagnosed necrotizing vasculitis [43], cutaneous vasculitis [44], and systemic lupus erythematosus (SLE)associated vasculitis [45]. In all but one case, the symptoms improved with ganciclovir, in association or not with prednisone.

Further, a previously healthy woman who acquired CMV mononucleosis developed vasculitis with antineutrophil cytoplasmic antibodies (c-ANCA). This patient had extraordinarily high plasma levels of IL-5 and 
lymphotoxin- $\alpha$ and developed autoantibodies, concomitant with the primary CMV infection. After the onset of vasculitis, CMV genomes were detected in the blood and urine, and CMV antigens were observed in inflammatory lesions of the kidney, suggesting that CMV triggers and maintains the autoimmune process [42].

Finally, CMV RNA was detected in endothelial cells from skin biopsies in patients who presented with sudden onset of autoimmune sclerosis. One patient was treated with ganciclovir, which did not improve the clinical course of the disease [44].

\section{A3. Induction of encephalitis associated with autoimmune phenomena}

Recently, a previously healthy woman who suffered from active CMV experienced abrupt onset of encephalitis that was associated with autoimmune phenomena. Primary CMV infection was diagnosed by serology, and CMV DNA was detected in the cerebrospinal fluid and blood at the onset of symptoms. Long-course treatment with ganciclovir and intravenous immunoglobulins and decreasing doses of cortisone improved the neurological status. Although viral replication was halted and immunosuppressive therapy was discontinued, extremely low levels of CMV-specific $\mathrm{CD} 4^{+}$and $\mathrm{CD} 8^{+} \mathrm{T}$ cells were detected for up to 10 months after disease onset. Conversely, high blood interferon (IFN) - $\gamma$ levels were observed, suggesting enhancement of nonspecific immune mechanisms that were activated to compensate for the lack of CMV-specific T cell responses (Xu, Varani et al., manuscript in preparation). This case suggests that CMV infection in subjects with potentially hidden immune defects can enhance viral replication that triggers autoimmune phenomena.

Although it is possible that they are unrelated with regard to causation, the concurrent active CMV infection and onset of autoimmunity that were observed in these cases suggest that CMV induces autoimmunity in predisposed individuals.

\section{A4. Increased risk for post-transplant diabetes mellitus}

Viral infections, such as enteroviruses and mumps virus, are believed to provoke type I diabetes in genetically predisposed individuals [46]. Clinical evidence suggests that asymptomatic CMV infection and CMV disease are independent risk factors for early-onset diabetes mellitus in recipients of renal transplant (generally referred to as PTDM) $[47,48]$. Further, CMV donor-positive/ recipient-negative serostatus is a risk factor for the development of PTDM in pediatric renal transplant patients [49], and active CMV infection predisposes adult liver transplant patients to the development of PTDM [50]. The incidence of PTDM has declined significantly since the introduction of preemptive antiCMV regimens, supporting the link between CMV and PTDM [51].
CMV damages $\beta$-cells by direct viral infection (the pancreas is a target organ of CMV infection [52]), through the cytotoxic effects of activated effector lymphocyte infiltrates, or the induction of proinflammatory cytokines [53]. There are limited experimental data on the inhibition of $\beta$-cell function by CMV, however, necessitating additional studies to demonstrate a causal relationship between CMV infection and PTDM.

\section{A5. Active infection during autoimmune disorders}

Current findings suggest that latent CMV can be reactivated by allogeneic stimulation in monocytes from seropositive donors [22] and that IFN- $\gamma$ and TNF- $\alpha$ are necessary for the differentiation of CMV-permissive M $\varphi s$ [54]. These findings have clinical implications, because immune-mediated processes that involve $\mathrm{T}$ cell activation and inflammation may facilitate the reactivation of latent CMV in monocytes in vivo. Thus, the chronic inflammation that is associated with autoimmune diseases might provide the ideal microenvironment in which latent CMV can be reactivated in M $\varphi s$; this inflammation can induce DC maturation, which can also provoke viral reactivation from latency [23].

\section{Inflammatory bowel diseases and other enteropathies} CMV replicates efficiently in epithelial cells of the intestinal mucosa $[55,56]$ and is a major cause of graft failure after intestinal transplantation [57]. In recent years, many studies have focused on the pathogenic function of CMV replication in inflammatory bowel disease (IBD). Notably, CMV antigens have been found in $10 \%$ to $90 \%$ of biopsies from patients with IBD [58-60]. Patients with inactive or mild to moderate ulcerative colitis (UC) [60,61] and Crohn disease [60-63] rarely show signs of CMV replication, whereas active CMV infection exists in $20 \%$ to $40 \%$ of steroid-refractory UC [63-73], suggesting that CMV exacerbates inflammation.

Antiviral treatment in patients with steroid-resistant $\mathrm{UC}$ and active CMV infection has been efficacious in isolated cases or small groups of patients $[63,65,68,70,71,74]$, whereas other studies have reported clinical improvements in CMV colitis in the absence of antiviral medication $[60,75,76]$, indicating the need for large, randomized, controlled studies to determine the true clinical value of antivirals in CMV-positive UC.

Notably, active CMV infection was diagnosed based on the detection of CMV in mucosal biopsy specimens from the colon by immunohistochemistry and PCR in the majority of these studies [60,63-66,68-70,72,77], whereas blood analysis, when performed, demonstrated low viral loads or the absence of viremia $[63,64]$. These findings imply that CMV replication occurs primarily in the colon of patients with UC.

Further, recent evidence has shown that all patients with steroid-refractory UC who have experienced active CMV infection have been previously CMV-seropositive, 
suggesting that the virus reactivated at the site of inflammation during the active phase of disease [63]. Latently infected monocytes [20] are recruited to the site of colonic inflammation, where monocyte activation and differentiation can induce viral reactivation [22,23]. Whether epithelial cells of the colonic mucosa carry latent CMV that contributes to viral reactivation is unknown.

Evidence indicates that CMV DNA can also be detected in intestinal biopsies of patients with common variable immunodeficiency (CVID) [78]. CVID is a heterogeneous disease that results in hypogammaglobulinemia, a propensity for infection and autoimmunity and that may also complicate with severe enteropathy. The role of CMV infection in triggering/worsening such disease is only partially understood; preliminary clinical observations suggest that an exaggerated $\mathrm{T}$ cell response to CMV may cause or exacerbate enteropathy in CVID [79], further underscoring the potential inflammatory role of CMV in the gastrointestinal tract.

Autoimmune disorders with major vascular involvement: vasculitis and systemic sclerosis Increasing evidence suggests that in addition to hepatitis $\mathrm{C}(\mathrm{HCV})$, other viruses, such as CMV, EBV, HIV, and parvovirus B19, accompany systemic vasculitis [80]. In such disorders, CMV infection coincides with the onset of inflammatory disease [42-45], as discussed, or with the initiation of immunosuppressive therapy [81]. Recently, IgM antibodies against CMV were observed more frequently in patients with c-ANCA-positive vasculitis compared with controls, while no other viral, bacterial and parasitic infections appeared to be involved [82]. Thus, CMV infection might initiate or maintain inflammation in vasculitides.

CMV has also been implicated as a trigger of vascular damage in systemic sclerosis [83]. The clinical onset of systemic sclerosis has been associated with the presence of an active CMV infection [44]. Further, autoantibodies that are specific for systemic sclerosis recognize the late CMV protein UL94 and are associated with the diffuse form of the disease but not the limited form, suggesting a correlation between the virus and disease severity $[84,85]$. Notably, antibodies against UL94 induce apoptosis in endothelial cells and activate dermal fibroblasts in vitro, effecting 2 hallmarks of systemic sclerosis-vascular damage and fibrosis [86].

Other autoimmune disorders Laboratory signs of acute CMV infection and anti-CMV have been observed in other autoimmune diseases. Subclinical systemic CMV infection develops in psoriatic patients and is associated with high levels of TNF- $\alpha$ [87]. Moreover, CMV DNA, specific antigens, and infectious virus particles have been detected in synovial tissue and fluid from the joints of $10 \%$ to $50 \%$ patients with rheumatoid arthritis (RA) [88-91].
Active CMV infection is also frequent in children with SLE [92], and CMV has been implicated in its development and exacerbation [93-97]. Serological signs of active CMV infection have been detected in $10 \%$ of patients with SLE, and the presence of viral infection is associated with higher disease activity scores [98]. Patients with SLE also have more robust humoral activity in response to CMV [99] and, in particular, to the CMV structural protein pp65 [100] compared with healthy donors and patients with other autoimmune disorders. In a recent study, CMV was the only infectious agent for which higher rates of IgM seropositivity and higher antibody titers were observed in SLE patients versus controls [101].

\section{B. Immunosuppression}

CMV infection (mainly primary infection) causes transient but substantial immunosuppression [102]. CMV effects immunosuppression in solid organ transplant recipients, potentiating superinfections with various pathogens [103]. Notably, meta-analyses of thousands of transplant recipients have demonstrated significant effects of anti-CMV prophylaxis in preventing bacterial and fungal [104] infections and bacterial and protozoan [105] infections. Further, in solid organ recipients, CMV replication influences the viral load of other viruses, such as human herpes virus (HHV)-6 and HHV-7 [106], and HCV load [107].

Owing to its immunosuppressive effect, CMV has also been suggested as a risk factor for the development of post-transplant lymphoproliferative disorders (PTLDs) in solid organ recipients, a pathological condition that is associated strictly with EBV replication [108]. In particular, CMV mismatch (donor positive/recipient negative) [109] and CMV disease [110] have been identified as general risk factors predisposing to the development of PTLD in solid organ transplant recipients. However, recent evidence shows no correlation between CMV disease and the development of PTLD [111-113]. Therefore, whether CMV is associated to an increased risk of PTLD is debatable and further studies are needed to clarify this matter.

$\mathrm{CMV}$ is immunosuppressive in allo-SCT recipients and death appears to be mediated by invasive bacterial and fungal infections, of which invasive aspergillosis is the most significant complication [114]. In addition, by preventing CMV replication in BMT recipients, a reduction in mortality as a result of all types of infections is achieved [115]. Finally, an increased risk of death from infections has been shown in CMV-seropositive BMT recipients receiving grafts from seronegative donors [114,116,117], supporting the importance of transferring specific $\mathrm{T}$ cells with the graft to control CMV replication and its immunomodulatory effects in this patient's cohort. 


\section{Graft rejection}

CMV promotes classical rejection and vasculopathy of an allograft, which impacts its longevity [6]. Several cohort studies have shown that CMV infection is associated with an increased risk of graft rejection in renal, liver, and lung transplant patients [118-121].

Studies in heart transplant recipients report that acute rejection and accelerated coronary atherosclerosis are linked to asymptomatic and symptomatic CMV infection $[122,123]$. Cardiac transplant vascular sclerosis, characterized histologically by diffuse concentric intimal proliferation that results in vessel stenosis and, ultimately, allograft failure [124], is highly associated with CMV in heart transplant recipients [125]. The higher incidence of viral DNA in explant vascular intima from patients with cardiac graft vascular sclerosis compared with explants without vasculopathy underscores the influence of CMV on the development of chronic rejection [126]. In addition, the early control of subclinical replication of CMV after cardiac transplantation by $\mathrm{T}$ cell immunity may reduce allograft vasculopathy and allograft rejection [127].

Chronic vasculopathy has also been associated with CMV in kidney transplant recipients [128]; bronchiolitis obliterans in lung recipients also correlates with CMV infection [119,129]. Several randomized trials of antiviral prophylaxis and preemptive therapy have demonstrated that antivirals provide significant protection against $\mathrm{CMV}$-associated allograft injury, providing the strongest evidence for the link between CMV infection and allograft rejection [104,130-133].

In BMT recipients, GVHD and CMV replication are pathogenetically associated; multiple studies show that GVHD and its treatment put patients at risk for CMV replication [134-136]. In contrast, the role of CMV replication as a cause of GVHD is controversial. Opposite findings have been published on the effect of CMV replication on development of acute GVHD [116,136-139]. Several studies showed that an increased risk of chronic GVHD was associated with CMV viremia $[35,137,140]$ and that BMT patients receiving pre-emptive therapy for CMV replication exhibited lower risks for severe chronic GVHD [141]. On the other hand, large randomized studies of prophylaxis with acyclovir or valacyclovir showing effects on CMV replication did not have any impact on the risk for GVHD [115,142].

\section{Mechanisms of CMV-induced immunopathology}

\section{A. Humoral autoimmunity}

The mechanisms by which CMV interacts with the immune response to induce autoimmune phenomena are unknown. One possibility is viral mimicry [143]. The CMV genome harbors a series of genes that are homologous to cellular genes; consequently, the host response to viral determinants can crossreact with host tissues, leading to autoimmunity (Figure 1A). This mechanism likely explains the generation of pathogenetic autoantibodies that crossreact with CMV during systemic sclerosis [83].

Humoral autoimmunity can also be elicited by nonspecific B cell activation that is caused by CMV. CMV is a polyclonal B-cell activator in vitro, and the $\mathrm{B}$ cell hyperresponse does not require viral replication [144]. In addition, CMV interacts with toll-like receptor (TLR) 7 and/or 9 in human plasmacytoid DCs, leading to secretion of IFN- $\alpha$ and B cell proliferation [145]. These DC-mediated events might facilitate polyclonal B cell activation and autoantibody production during CMV infection (Figure 1A).

B cell hyperactivation has clinical implications for infected patients, as demonstrated in transplant recipients, wherein autoantibodies contribute to the development of GVHD in CMV-infected alloSCT patients and to graft rejection in solid organ recipients $[34,35,38,39]$.

\section{B. Inflammation}

Primary and latent CMV infections induce chronic, systemic type 1 inflammatory responses [7]. Such sustained immune activation can augment alloimmune responses by enhancing the expansion and function of alloreactive $\mathrm{T}$ cells after transplantation. Moreover, the protracted elevation in serum IFN- $\gamma$ levels can increase major histocompatibility complex (MHC) expression on graft cells, raising the risk of recognition by alloantigen-specific $\mathrm{T}$ cells. Both mechanisms can mediate allograft rejection.

The primary involvement of IFN- $\gamma$, T-bet (functional markers of Th1 CD4 ${ }^{+} \mathrm{T}$ cells), and granzyme B (a cytotoxic marker of $\mathrm{CD}^{+}$cells) in the pathogenesis of transplant glomerulopathy [146], a major risk factor for chronic graft rejection, has been demonstrated recently, implicating Th1-inducing CMV in chronic rejection in renal transplant recipients. Immune-mediated damage, involving $\mathrm{CD}^{+}$granzyme $^{+}$cytotoxic $\mathrm{T}$ cells, has also been observed in fetuses that are severely affected by congenital CMV infections (Gabrielli, Landini et al., manuscript in preparation). As discussed below, inflammation might enhance autoimmunity when CMV has reactivated in autoimmune diseases.

\section{Generation of $\mathrm{CD} 4^{+} \mathrm{CD} 28^{\text {null }} T$ cells}

A unique subset of $\mathrm{CD}^{+}{ }^{+} \mathrm{T}$ cells that lack the costimulatory molecule CD28 expand in patients with autoimmune diseases, such as RA, Wegener's granulomatosis, dermatomyositis and polymyositis, multiple sclerosis, and IBD [147-150]. These cells have pathogenic properties in vitro [151], are a major source of Th1 cytokines in lesions in Wegener's granulomatosis [152], and are associated with early atherosclerotic vessel damage in RA patients [153]. In addition, $\mathrm{CD} 4^{+} \mathrm{CD} 28^{-}$and $\mathrm{CD} 8$ 


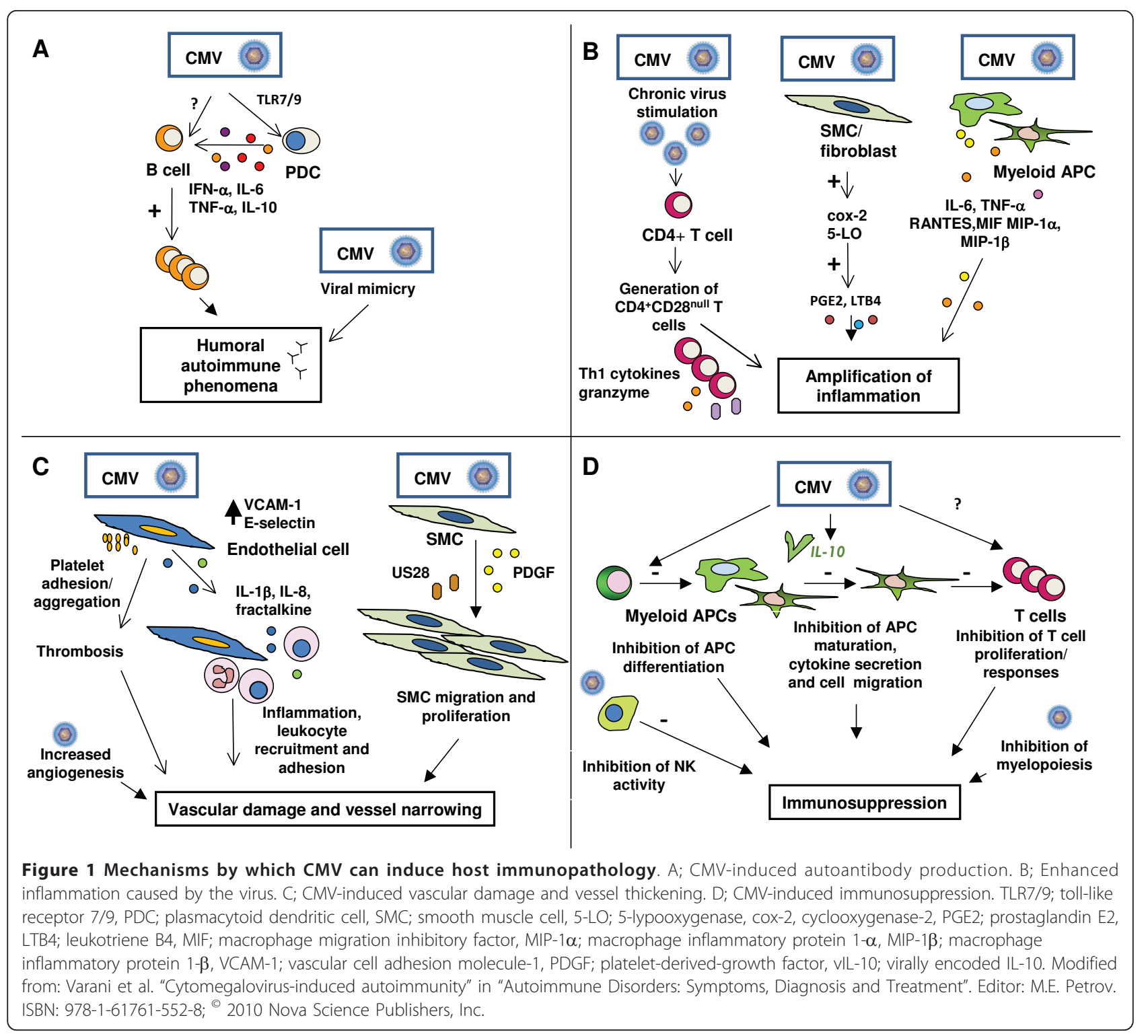

${ }^{+} \mathrm{CD} 28^{-} \mathrm{T}$ cells are the predominant $\mathrm{T}$ cells that infiltrate inflamed muscles in patients with dermatomyositis and polymyositis, secreting IFN- $\gamma$ on CMV-specific antigenic stimulation [150].

Notably, $\mathrm{CD} 4^{+} \mathrm{CD} 28^{-} \mathrm{T}$ cells appear to exist almost exclusively in CMV-infected individuals [150,154]. In RA patients and healthy controls, $\mathrm{CD} 4^{+} \mathrm{CD} 28^{-}$lymphocytes react specifically with several CMV epitopes [151]. Thus, CMV replication in inflammatory lesions has been speculated to drive the differentiation of $\mathrm{CD}_{4}{ }^{+} \mathrm{T}$ cells into pathogenic CD28 $8^{\text {null }} \mathrm{T}$ cells, thereby aggravating local chronic inflammation in autoimmune disorders [151] (Figure 1B).

\section{$N F-k B$ and other inflammatory factors}

In addition to inducing the end-stage differentiation of pathogenic T cells, CMV sustains chronic inflammation through other mechanisms. In vitro, CMV infection stimulates the translocation of NF-kB into the nucleus, which then upregulates TNF- $\alpha$, leading to further activation of latent CMV and inflammatory responses [155].

CMV induces transient cyclooxygenase 2 expression in infected fibroblasts and the subsequent release of prostaglandin E2, a mediator of inflammation [156]. CMV also stimulates 5-lypoxygenase expression, which is crucial for the synthesis of leukotriene B4, a powerful chemoattractant [157] (Figure 1B). In addition, CMV infects various subsets of myeloid antigen-presenting cells (APCs) efficiently [158-160] that, once infected, release myriad inflammatory mediators [160-162] (Figure 1B). These mechanisms might sustain inflammation in CMVinfected lesions in autoimmune disorders and CMVpositive allografts. 


\section{Vascular damage and stenosis}

Viral infections mediate the pathogenesis of vascular damage and vascular stenosis through various mechanisms, such as the infection of endothelial cells, causing cellular dysfunction or death; immune-mediated injury of the vessel wall; hemorheological dysfunction due to increased procoagulant activity; and migration and proliferation of smooth muscle cells [163-165].

CMV can productively infect endothelial cells in vitro [166-168] and CMV-infected endothelial cells are dysfunctional, due to diminished expression and activity of endothelial nitric oxide synthase [169]; augmented release of IL-8, a regulator of neutrophil migration [170]; increased secretion of the proinflammatory cytokine IL-1 $\beta$; and upregulation of adhesion molecules that promote leukocyte adhesion [171] (Figure 1C).

The function of virus-induced cytokines and chemokines in the initiation and exacerbation of vascular damage is a growing area of research. CMV induces the release of proinflammatory cytokines and chemokines and encodes $\mathrm{CC}$ and $\mathrm{CXC}$ chemokine homologs that recruit cellular infiltrates [165]. In addition, during host $\mathrm{CD}^{+} \mathrm{T}$ cell responses to $\mathrm{CMV}$ antigens, sufficient levels of IFN- $\gamma$ and TNF- $\alpha$ are generated to induce the expression of fractalkine in endothelial cells [172]. On such upregulation, fractalkine mediates the recruitment and mobilization of natural killer (NK) cells and monocytes, which damage endothelial cells [173]. Thus, CMV-associated chronic endothelial cell inflammation and damage result from chemokine-mediated immunopathogenic effects (Figure 1C).

CMV infection can modulate the activity of the endothelium-from anticoagulant to procoagulant [174]and induce platelet adherence and aggregation in infected endothelium [175]. Such effects can aggravate the vascular damage that is induced by CMV and induce vascular inflammation (Figure 1C). Endothelial cell damage, cytokine and chemokine release, and cellular dysfunction likely contribute to allograft-associated vasculopathy [165].

In addition to endothelial cells, CMV productively infects all cell types that are involved in vascular rejection, including smooth muscle cells (SMCs), M $\varphi s$, and fibroblasts. The migration of SMCs from the media into the neointimal space and their subsequent proliferation are hallmarks of the development of vascular lesions during allograft vasculopathy.

CMV blocks apoptosis through various mechanisms [176], which effects the accumulation of SMCs. CMV also induces the production of potent stimuli of SMC proliferation, such as platelet-derived growth factor [177]. In addition, by generating the chemokine receptor US28, CMV enhances SMC migration [178]. The resulting accumulation of SMCs in the vessel intima on CMV infection leads to neointimal hyperplasia and vessel narrowing. Activated inflammatory cells, fibroblasts, and SMCs within vascular lesions are important local sources of factors that promote angiogenesis [179], which accelerates the development of transplant vascular sclerosis (Figure 1C).

\section{Immunosuppression}

Because CMV induces a robust and chronic antigenic response in immunocompetent individuals that increases with age [180], it has evolved several mechanisms to suppress and evade this response and persist in the host. Such mechanisms lead to transient but substantial immunosuppression against the virus itself and unrelated pathogens [181].

CMV-induced impairments that impede host immune responses have been demonstrated in vivo and in vitro. For example, patients with CMV mononucleosis experience a loss in delayed-type hypersensitivity reactions to recall antigens [182] and reduced lymphoproliferative responses to mitogens [183] and specific antigens [184]. In immunocompetent adolescents with asymptomatic primary CMV infections, lymphocyte proliferation in response to $\mathrm{CMV}$ is less robust than in seropositive controls [26]. Specific cell-mediated immunity is also attenuated in children with congenital [185] and acquired [186] CMV infections.

In vitro, CMV suppresses lymphocyte proliferation to $\mathrm{T}$ cell mitogens and prevents lymphocytes and monocytes from producing and responding to immune mediators, such as IL-1 and IL-2 [187]. In addition, CMV inhibits cytotoxic and NK cell activity $[188,189]$. CMV suppresses bone marrow myelopoiesis by infecting hematopoietic progenitors and their progeny directly or infecting stromal cells and altering the bone marrow microenvironment [190-192].

These observations are supported by evidence of impaired APC function on infection with CMV, including altered phagocytosis, differentiation, migration and maturation, and reduced expression of MHC molecules, preventing effective antigen presentation to $\mathrm{T}$ cells [160,162,187,193-199]. CMV impairs the ability of plasmacytoid DCs to induce allogeneic $\mathrm{T}$ cell proliferation [145], indicating broad virus-induced inhibition of various APC subsets.

The secretion of cmvIL-10 during CMV infection might aid the virus in infecting and inhibiting DCs chronically [200,201] (Figure 1D). CMV might use these mechanisms as immunoevasive strategies and simultaneously effect robust and broad inhibition of host immunity.

\section{Treatment of virus-induced immunopathology}

Despite the substantial progress in transplantology, CMV continues to be a significant cause of morbidity in 
transplant recipients, due to its many direct and indirect effects. While the direct effects of CMV infection are well managed by treatment with ganciclovir or its prodrug, valganciclovir, the optimal therapy for treating and preventing virus-induced immunopathology remains undefined [6]. Studies indicate that antiviral prophylaxis provides significant protection against $\mathrm{CMV}$-associated allograft injury and immunosuppression $[104,105,130,131]$. However, no guidelines on the treatment of virus-induced immunopathology in transplant recipients exist. Similarly, little is known about the treatment of viral immunomodulation in patients with autoimmune disorders.

When CMV replication is detected in patients with autoimmune diseases, clinicians are faced with a therapeutic dilemma: should antiviral therapy be initiated and immunosuppression be reduced to generate specific antiviral immune responses, despite the risk of exacerbating the autoimmune disorder? Or, should the doses of immunosuppressive agents be increased to suppress inflammatory activity? Similarly, the treatment of CMV infection that accompanies allograft rejection in solid organ transplant recipients is complicated, because the modulation of iatrogenic immunosuppression can oppositely influence CMV replication and the rejection episode [202].

As discussed, in 5 patients with vasculitis who tested positive for active CMV infection, remission of the autoimmunity was achieved on treatment with ganciclovir alone or with CMV immunoglobulin and/or cortisone [43-45]. We also effected a successful outcome in a patient who developed encephalitis and autoimmune phenomena on primary CMV infection after a longcourse treatment with ganciclovir and intravenous immunoglobulins and decreasing doses of prednisone (Xu, Varani et al., manuscript in preparation). The positive outcomes in these cases suggest that a 2-pronged approach-comprising the inhibition of viral replication by antivirals and immunomodulation by intravenous IgG [203] and/or prednisone-is warranted when the onset of autoimmune disorders coincides with active CMV infection.

Increasing evidence shows that CMV exacerbates the clinical outcome of UC, prompting the hypothesis that antiviral therapy or another regimen that impedes viral replication is beneficial when CMV infection is histologically proven at the site of inflammation [63]. To this end, 3 therapeutic options have been considered; 1 . administration of antiviral compounds, 2. modulation of immunosuppression, and 3. modulation of inflammation.

Many studies have reported successful outcomes using antivirals, such as ganciclovir and oral valganciclovir, in isolated cases or small groups of patients with steroid-refractory UC and active CMV infection $[63,65,68,70,71,74]$. Recently, it has been suggested that all UC patients with severe colitis that is refractory to immunosuppressants be tested for CMV reactivation and receive antiviral therapy if colonic CMV is detected [204].

Modulating immunosuppressive therapy elicits stronger anti-CMV immune responses; this option has been used successfully alone [64] or with antivirals [64,67,71].

Because CMV reactivation depends strictly on inflammation [10], treatments that reduce colonic inflammation, such as anti-TNF- $\alpha$ compounds and leukapheresis, can reduce viral replication in UC patients, as shown by 2 recent reports [74,205].

Thus, the use of antivirals and indirect suppression of viral replication might be effective treatments for CMVpositive refractory UC. However, large, randomized, controlled studies are needed to determine their efficacies in UC patients and other patients with autoimmune disorders who experience active CMV infection.

\section{Conclusion}

During acute CMV infection, patients often suffer from immunological dysfunctions. Autoimmune phenomena are common in CMV-infected patients, and various autoantibodies have been detected in patients with systemic CMV infection [32-34,36,37,42]. Nonspecific hyperactivation of humoral immunity can impede the development of specific B cell responses-a potential mechanism of viral immune evasion. Such a phenomenon has clinical implications for infected patients, as demonstrated in transplant recipients-autoantibodies mediate the development of GVHD in CMV-infected alloSCT patients and graft rejection in solid organ recipients [34,35,38,39] (Figure 2).

In potentially predisposed patients, primary CMV infections can trigger autoimmune disorders, and vasculitides and scleroderma develop concomitantly with or immediately after active CMV infection in previously healthy, immunocompetent subjects [42-45]. In addition to acute systemic CMV infection, low-grade CMV replication appears to be a frequent event in autoimmune disorders [206]. CMV can accelerate the progression of autoimmune disorders by mimicking autoimmunemediated tissue destruction and aggravating inflammation. Local viral replication is also associated with chronic perivascular inflammation in solid organ transplant recipients (Figure 2). In these patients, CMV persists in the allograft, but few cells are infected directly by CMV. These findings contrast the global effects that CMV has on the acceleration of vascular stenosis and chronic rejection, suggesting that CMV does not promote vascular disease through direct infection of vessels; instead, it likely acts by indirect mechanisms that in part involve the immune system [179].

Paradoxically, CMV infection, principally primary infection, induces transient but significant immunosuppression, 


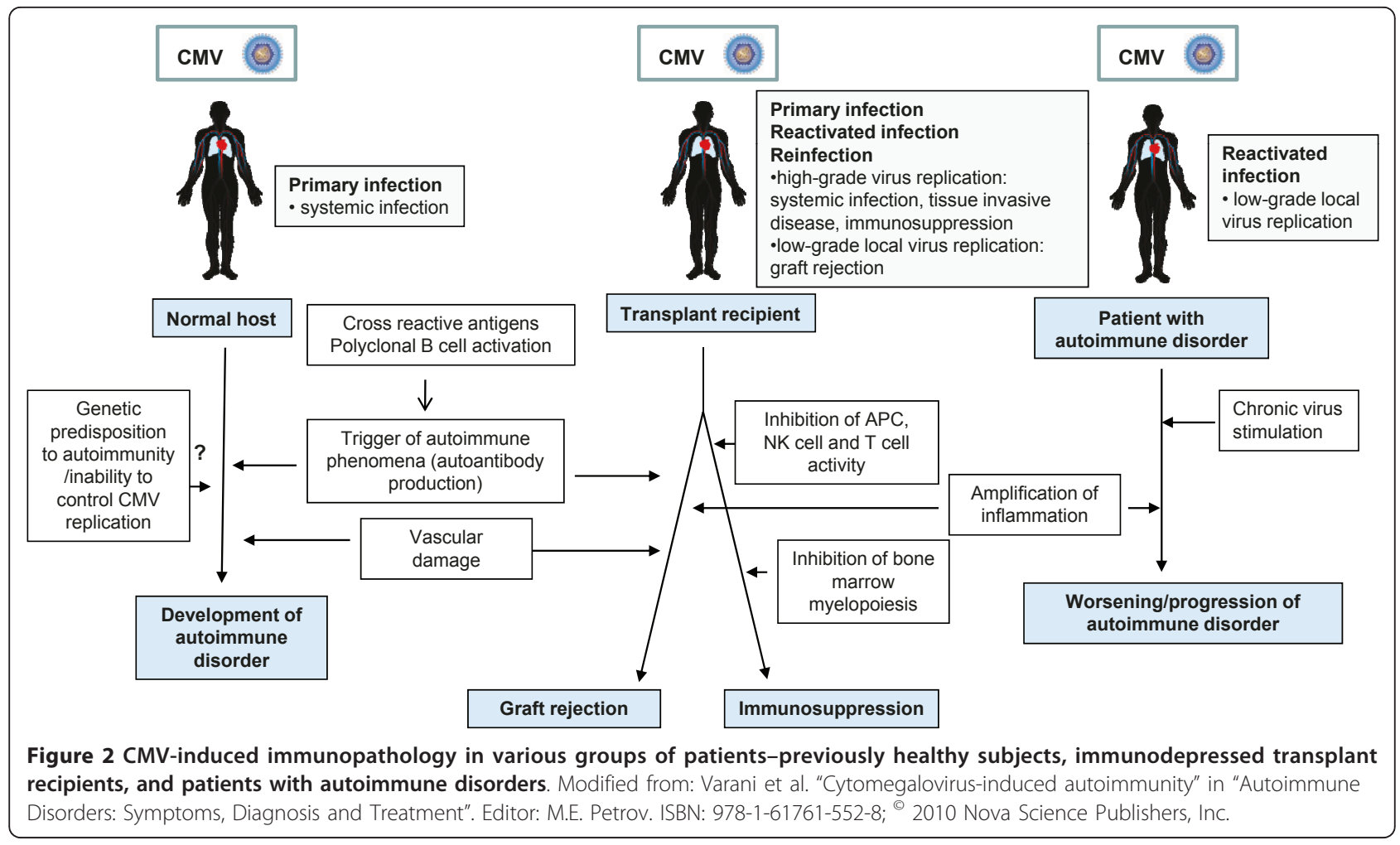

which has clinical consequences during active CMV infection in transplant recipients; such patients develop increased risk for opportunistic infections that can be reduced significantly by antiviral prophylaxis [103-105,114] (Figure 2).

Herpesviruses are archetypal persistent infectious agents that, even in individuals with essentially normal immunity, escape occasionally from normal immune control and cause symptomatic disease. Of all herpesviruses, CMV harbors the most genes that are committed to altering innate and adaptive host immunity [4], and a significant fraction of the $\mathrm{T}$ cell repertoire in CMV carriers is directed against this virus [1]. Because CMV persists in the host, it can be erroneously implicated in the pathogenesis of various diseases despite its lack of involvement. Nevertheless, examples of immunopathology that are attributed to CMV continue to accumulate, suggesting that this virus has critical immunomodulatory functions.

\footnotetext{
Abbreviations

(alloSCT): allogeneic stem cell transplant; (ANCA): antineutrophil cytoplasmic antibody; (APC): antigen presenting cell; (BMT): bone marrow transplant recipient; (CMV): human cytomegalovirus; (CVID): common variable immunodeficiency; (DC): dendritic cell; (E): early; (EBV): Epstein-Barr virus; (GVHD): graft-versus-host disease; (HCV): hepatitis C virus; (HHV): human herpes virus; (IBD): inflammatory bowel disease; (IE): immediate early; (IFN): interferon; (L): late; $(\mathrm{MHC})$ : major histocompatibility complex; $(\mathrm{M \varphi})$ : macrophage; (NF-kB): nuclear factor-kB; (NK): natural killer; (PTDM): posttransplant diabetes mellitus; (PTLD): post-transplant lymphoproliferative
}

disorder; (RA): rheumatoid arthritis; (SLE): systemic lupus erythematosus; (SMC): smooth muscle cell; (TLR): toll-like receptor; (TNF): tumor necrosis factor; (UC): ulcerative colitis.

\section{Acknowledgements}

This work was supported by the Italian Ministry of University and Scientific Research (PRIN 2007 to M.P.L.) and RFO, University of Bologna (S.V. and M.P. L.). The manuscript was edited by Blue Pencil Science.

\section{Authors' contributions}

SV and MPL conceived and wrote the manuscript. The authors read and approved the final manuscript.

\section{Competing interests}

The authors declare that they have no competing interests.

Received: 27 January 2011 Accepted: 7 April 2011

Published: 7 April 2011

\section{References}

1. Mocarski ES, Shenk T, Pass R: Cytomegaloviruses. In Fields Virology. Volume 2.. Fifth edition. Edited by: Knipe D, Howley P. Lippincott Williams and Wilkins; 2007: 2701-2772.

2. Murphy E, Yu D, Grimwood J, Schmutz J, Dickson M, Jarvis MA, Hahn G, Nelson JA, Myers RM, Shenk TE: Coding potential of laboratory and clinical strains of human cytomegalovirus. Proc Natl Acad Sci USA 2003, 100: 14976-14981.

3. Dunn W, Chou C, Li H, Hai R, Patterson D, Stolc V, Zhu H, Liu F: Functional profiling of a human cytomegalovirus genome. Proc Natl Acad Sci USA 2003, 100: 14223-14228.

4. Miller-Kittrell M, Sparer TE: Feeling manipulated: cytomegalovirus immune manipulation. Virol J 2009, 6: 4

5. Sinzger C, Jahn G: Human cytomegalovirus cell tropism and pathogenesis. Intervirology 1996, 39: 302-319.

6. Rubin RH: The pathogenesis and clinical management of cytomegalovirus infection in the organ transplant recipient: the end of the 'silo hypothesis'. Curr Opin Infect Dis 2007, 20: 399-407. 
7. van de Berg PJ, Heutinck KM, Raabe R, Minnee RC, Young SL, van Donselaar-van der Pant KA, Bemelman FJ, van Lier RA, ten Berge IJ: Human cytomegalovirus induces systemic immune activation characterized by a type 1 cytokine signature. J Infect Dis 2010, 202: 690-699.

8. Britt W: Manifestations of human cytomegalovirus infection: proposed mechanisms of acute and chronic disease. Curr Top Microbiol Immunol 2008, 325: 417-470.

9. Decrion AZ, Dichamp I, Varin A, Herbein G: HIV and inflammation. Curr HIV Res 2005, 3: 243-259.

10. Docke WD, Prosch S, Fietze E, Kimel V, Zuckermann H, Klug C, Syrbe U, Kruger DH, von Baehr R, Volk HD: Cytomegalovirus reactivation and tumour necrosis factor. Lancet 1994, 343: 268-269.

11. Docke WD, Kiessling C, Worm M, Friedrich M, Pruss A, Weitz M, Prosch S, Kern F, Volk HD, Sterry W, et al: Subclinical activation of latent cytomegalovirus (CMV) infection and anti-CMV immune response in patients with atopic dermatitis. Br J Dermatol 2003, 148: 954-963.

12. Kutza AS, Muhl E, Hackstein H, Kirchner H, Bein G: High incidence of active cytomegalovirus infection among septic patients. Clin Infect Dis 1998, 26: 1076-1082.

13. von Muller L, Klemm A, Durmus N, Weiss M, Suger-Wiedeck H, Schneider M, Hampl W, Mertens T: Cellular immunity and active human cytomegalovirus infection in patients with septic shock. J Infect Dis 2007, 196: 1288-1295.

14. Guyotat D, Gibert R, Chomel J, Archimbaud E, Bossard S, Maupas J, Fiere D, Aymard M: Incidence and prognosis of cytomegalovirus infections following allogenic bone marrow transplantation. J Med Virol 1987, 23 393-399.

15. Koskinen PK, Kallio EA, Tikkanen JM, Sihvola RK, Hayry PJ, Lemstrom KB: Cytomegalovirus infection and cardiac allograft vasculopathy. Transp/ Infect Dis 1999, 1: 115-126.

16. Lautenschlager I, Hockerstedt K, Taskinen E, von Willebrand E: Expression of adhesion molecules and their ligands in liver allografts during cytomegalovirus (CMV) infection and acute rejection. Transpl Int 1996, 9(Suppl 1): S213-215.

17. Ricart MJ, Malaise J, Moreno A, Crespo M, Fernandez-Cruz L: Cytomegalovirus: occurrence, severity, and effect on graft survival in simultaneous pancreas-kidney transplantation. Nephrol Dial Transplant 2005, 20(Suppl 2): ii25-ii32, ii62.

18. Kline JN, Hunninghake GM, He B, Monick MM, Hunninghake GW: Synergistic activation of the human cytomegalovirus major immediate early promoter by prostaglandin E2 and cytokines. Exp Lung Res 1998, 24: 3-14.

19. Prosch S, Wendt CE, Reinke P, Priemer C, Oppert M, Kruger DH, Volk HD Docke WD: A novel link between stress and human cytomegalovirus (HCMV) infection: sympathetic hyperactivity stimulates HCMV activation. Virology 2000, 272: 357-365.

20. Taylor-Wiedeman J, Sissons JG, Borysiewicz LK, Sinclair JH: Monocytes are a major site of persistence of human cytomegalovirus in peripheral blood mononuclear cells. J Gen Virol 1991, 72(Pt 9): 2059-2064.

21. Mendelson M, Monard S, Sissons P, Sinclair J: Detection of endogenous human cytomegalovirus in CD34+ bone marrow progenitors. J Gen Virol 1996, 77(Pt 12): 3099-3102

22. Soderberg-Naucler C, Fish KN, Nelson JA: Reactivation of latent human cytomegalovirus by allogeneic stimulation of blood cells from healthy donors. Cell 1997, 91: 119-126.

23. Reeves MB, MacAry PA, Lehner PJ, Sissons JG, Sinclair JH: Latency, chromatin remodeling, and reactivation of human cytomegalovirus in the dendritic cells of healthy carriers. Proc Natl Acad Sci USA 2005, 102: 4140-4145.

24. Hecker M, Qiu D, Marquardt K, Bein G, Hackstein H: Continuous cytomegalovirus seroconversion in a large group of healthy blood donors. Vox Sang 2004, 86: 41-44.

25. Ziemann M, Unmack A, Steppat D, Juhl D, Gorg S, Hennig H: The natural course of primary cytomegalovirus infection in blood donors. Vox Sang 2010, 99: 24-33.

26. Zanghellini F, Boppana SB, Emery VC, Griffiths PD, Pass RF: Asymptomatic primary cytomegalovirus infection: virologic and immunologic features. J Infect Dis 1999, 180: 702-707.

27. Kotton CN: Management of cytomegalovirus infection in solid organ transplantation. Nat Rev Nephrol 2010, 6: 711-721.
28. Pereyra F, Rubin RH: Prevention and treatment of cytomegalovirus infection in solid organ transplant recipients. Curr Opin Infect Dis 2004, 17: 357-361.

29. Freeman RB Jr: The 'indirect' effects of cytomegalovirus infection. Am J Transplant 2009, 9: 2453-2458.

30. Fishman JA, Emery $V$, Freeman $R$, Pascual M, Rostaing $L$, Schlitt $H J$, Sgarabotto D, Torre-Cisneros J, Uknis ME: Cytomegalovirus in transplantation - challenging the status quo. Clin Transplant 2007, 21: 149-158.

31. Barry SM, Johnson MA, Janossy G: Cytopathology or immunopathology? The puzzle of cytomegalovirus pneumonitis revisited. Bone Marrow Transplant 2000, 26: 591-597.

32. Hebart $H$, Einsele $H$, Klein R, Fischer I, Buhler S, Dietz K, Jahn G, Berg PA, Kanz L, Muller CA: CMV infection after allogeneic bone marrow transplantation is associated with the occurrence of various autoantibodies and monoclonal gammopathies. Br J Haematol 1996, 95 138-144.

33. Mengarelli A, Minotti C, Palumbo G, Arcieri P, Gentile G, lori AP, Arcese W, Mandelli F, Avvisati G: High levels of antiphospholipid antibodies are associated with cytomegalovirus infection in unrelated bone marrow and cord blood allogeneic stem cell transplantation. Br J Haematol 2000, 108: 126-131.

34. Soderberg C, Sumitran-Karuppan S, Ljungman P, Moller E: CD13-specific autoimmunity in cytomegalovirus-infected immunocompromised patients. Transplantation 1996, 61: 594-600.

35. Soderberg C, Larsson S, Rozell BL, Sumitran-Karuppan S, Ljungman P, Moller E: Cytomegalovirus-induced CD13-specific autoimmunity-a possible cause of chronic graft-vs-host disease. Transplantation 1996, 61 600-609.

36. Toyoda M, Galfayan K, Galera OA, Petrosian A, Czer LS, Jordan SC: Cytomegalovirus infection induces anti-endothelial cell antibodies in cardiac and renal allograft recipients. Transpl Immunol 1997, 5: 104-111.

37. Varani S, Muratori L, De Ruvo N, Vivarelli M, Lazzarotto T, Gabrielli L, Bianchi FB, Bellusci R, Landini MP: Autoantibody appearance in cytomegalovirus-infected liver transplant recipients: correlation with antigenemia. J Med Virol 2002, 66: 56-62.

38. Fredrich R, Toyoda M, Czer LS, Galfayan K, Galera O, Trento A, Freimark D, Young S, Jordan SC: The clinical significance of antibodies to human vascular endothelial cells after cardiac transplantation. Transplantation 1999, 67: 385-391.

39. Dubel L, Farges $O$, Johanet $C$, Sebagh M, Bismuth $H$ : High incidence of antitissue antibodies in patients experiencing chronic liver allograft rejection. Transplantation 1998, 65: 1072-1075

40. Kantor GL, Goldberg LS, Johnson BL Jr, Derechin MM, Barnett EV: Immunologic abnormalities induced by postperfusion cytomegalovirus infection. Ann Intern Med 1970, 73: 553-558.

41. Wager O, Rasanen JA, Hagman A, Klemola E: Mixed cryoimmunoglobulinaemia in infectious mononucleois and Cytomegalovirus mononucleosis. Int Arch Allergy Appl Immunol 1968, 34: 345-361.

42. Varani S, Mastroianni A, Frascaroli G, Tammik C, Rahbar A, Christensson M, Rossini G, Landini MP, Soderberg-Naucler C: Generalized Wegener's granulomatosis in an immunocompetent adult after cytomegalovirus mononucleosis and bacterial urinary tract infection. Arthritis Rheum 2009, 60: 1558-1562.

43. Meyer MF, Hellmich B, Kotterba S, Schatz H: Cytomegalovirus infection in systemic necrotizing vasculitis: causative agent or opportunistic infection? Rheumatol Int 2000, 20: 35-38.

44. Magro CM, Crowson AN, Ferri C: Cytomegalovirus-associated cutaneous vasculopathy and scleroderma sans inclusion body change. Hum Pathol 2007, 38: 42-49.

45. Perez-Mercado AE, Vila-Perez S: Cytomegalovirus as a trigger for systemic lupus erythematosus. J Clin Rheumatol 2010, 16: 335-337.

46. Jaeckel E, Manns M, Von Herrath M: Viruses and diabetes. Ann N Y Acad Sci 2002, 958: 7-25.

47. Hjelmesaeth J, Sagedal S, Hartmann A, Rollag H, Egeland T, Hagen M, Nordal KP, Jenssen T: Asymptomatic cytomegalovirus infection is associated with increased risk of new-onset diabetes mellitus and impaired insulin release after renal transplantation. Diabetologia 2004, 47: 1550-1556. 
48. Hjelmesaeth J, Hartmann A, Kofstad J, Stenstrom J, Leivestad T, Egeland T, Fauchald P: Glucose intolerance after renal transplantation depends upon prednisolone dose and recipient age. Transplantation 1997, 64: 979-983.

49. Burroughs TE, Swindle JP, Salvalaggio PR, Lentine KL, Takemoto SK, Bunnapradist S, Brennan DC, Schnitzler MA: Increasing incidence of newonset diabetes after transplant among pediatric renal transplant patients. Transplantation 2009, 88: 367-373.

50. Driscoll CJ, Cashion AK, Hathaway DK, Thompson C, Conley Y, Gaber O, Vera S, Shokouh-Amiri H: Posttransplant diabetes mellitus in liver transplant recipients. Prog Transplant 2006, 16: 110-116.

51. Valderhaug TG, Hjelmesaeth J, Rollag H, Leivestad $T$, Roislien J, Jenssen $T$, Hartmann A: Reduced incidence of new-onset posttransplantation diabetes mellitus during the last decade. Transplantation 2007, 84: 1125-1130.

52. Kamalkumar BS, Agarwal SK, Garg P, Dinda A, Tiwari SC: Acute pancreatitis with CMV papillitis and cholangiopathy in a renal transplant recipient. Clin Exp Nephrol 2009, 13: 389-391.

53. Hjelmesaeth J, Muller F, Jenssen T, Rollag H, Sagedal S, Hartmann A: Is there a link between cytomegalovirus infection and new-onset posttransplantation diabetes mellitus? Potential mechanisms of virus induced beta-cell damage. Nephrol Dial Transplant 2005, 20: 2311-2315.

54. Soderberg-Naucler C, Fish KN, Nelson JA: Interferon-gamma and tumor necrosis factor-alpha specifically induce formation of cytomegaloviruspermissive monocyte-derived macrophages that are refractory to the antiviral activity of these cytokines. J Clin Invest 1997, 100: 3154-3163.

55. Goodgame RW: Gastrointestinal cytomegalovirus disease. Ann Intern Med 1993, 119: 924-935.

56. Esclatine A, Lemullois M, Servin AL, Quero AM, Geniteau-Legendre M: Human cytomegalovirus infects Caco-2 intestinal epithelial cells basolaterally regardless of the differentiation state. J Virol 2000, 74: 513-517.

57. Chiereghin A, Gabrielli L, Zanfi C, Petrisli E, Lauro A, Piccirilli G, Baccolini F, Dazzi A, Cescon M, Morelli MC, et al: Monitoring cytomegalovirus T-cell immunity in small bowel/multivisceral transplant recipients. Transplant Proc 2010, 42: 69-73.

58. Rahbar A, Bostrom L, Lagerstedt U, Magnusson I, Soderberg-Naucler C, Sundqvist VA: Evidence of active cytomegalovirus infection and increased production of IL- 6 in tissue specimens obtained from patients with inflammatory bowel diseases. Inflamm Bowel Dis 2003, 9: 154-161.

59. Dimitroulia E, Spanakis N, Konstantinidou AE, Legakis NJ, Tsakris A: Frequent detection of cytomegalovirus in the intestine of patients with inflammatory bowel disease. Inflamm Bowel Dis 2006, 12: 879-884.

60. Kim JJ, Simpson N, Klipfel N, Debose R, Barr N, Laine L: Cytomegalovirus infection in patients with active inflammatory bowel disease. Dig Dis Sci 2010, 55: 1059-1065.

61. Knosel T, Schewe C, Petersen N, Dietel M, Petersen I: Prevalence of infectious pathogens in Crohn's disease. Pathol Res Pract 2009, 205: 223-230.

62. Kojima T, Watanabe T, Hata K, Shinozaki M, Yokoyama T, Nagawa H: Cytomegalovirus infection in ulcerative colitis. Scand J Gastroenterol 2006, 41: 706-711.

63. Domenech E, Vega R, Ojanguren I, Hernandez A, Garcia-Planella E, Bernal I, Rosinach M, Boix J, Cabre E, Gassull MA: Cytomegalovirus infection in ulcerative colitis: a prospective, comparative study on prevalence and diagnostic strategy. Inflamm Bowel Dis 2008, 14: 1373-1379.

64. Yoshino T, Nakase H, Ueno S, Uza N, Inoue S, Mikami S, Matsuura M, Ohmori K, Sakurai T, Nagayama S, et al: Usefulness of quantitative realtime PCR assay for early detection of cytomegalovirus infection in patients with ulcerative colitis refractory to immunosuppressive therapies. Inflamm Bowel Dis 2007, 13: 1516-1521.

65. Wada Y, Matsui T, Matake H, Sakurai T, Yamamoto J, Kikuchi Y, Yorioka M, Tsuda S, Yao T, Yao S, et al: Intractable ulcerative colitis caused by cytomegalovirus infection: a prospective study on prevalence, diagnosis, and treatment. Dis Colon Rectum 2003, 46: S59-65.

66. Takahashi Y, Tange T: Prevalence of cytomegalovirus infection in inflammatory bowel disease patients. Dis Colon Rectum 2004, 47 722-726.

67. Papadakis KA, Tung JK, Binder SW, Kam LY, Abreu MT, Targan SR, Vasiliauskas EA: Outcome of cytomegalovirus infections in patients with inflammatory bowel disease. Am J Gastroenterol 2001, 96: 2137-2142.
68. Minami M, Ohta M, Ohkura T, Ando T, Ohmiya N, Niwa Y, Goto H: Cytomegalovirus infection in severe ulcerative colitis patients undergoing continuous intravenous cyclosporine treatment in Japan. World J Gastroenterol 2007, 13: 754-760.

69. Kuwabara A, Okamoto H, Suda T, Ajioka Y, Hatakeyama K: Clinicopathologic characteristics of clinically relevant cytomegalovirus infection in inflammatory bowel disease. J Gastroenterol 2007, 42: 823-829.

70. Kambham N, Vij R, Cartwright CA, Longacre T: Cytomegalovirus infection in steroid-refractory ulcerative colitis: a case-control study. Am J Surg Pathol 2004, 28: 365-373

71. Cottone M, Pietrosi G, Martorana G, Casa A, Pecoraro G, Oliva L, Orlando A, Rosselli M, Rizzo A, Pagliaro L: Prevalence of cytomegalovirus infection in severe refractory ulcerative and Crohn's colitis. Am J Gastroenterol 2001, 96: 773-775

72. Barahona-Garrido J, Martinez-Benitez B, Espinosa-Cardenas E, Sarti HM, Gutierrez-Manjarrez JI, Aguirre-Gutierrez R, Tellez-Avila FI, Coss-Adame E, Garcia-Juarez I, Yamamoto-Furusho JK: Cytomegalovirus infection in patients who required colectomy for toxic megacolon or severe steroidrefractory ulcerative colitis. Dig Dis Sci 2010, 55: 867-868.

73. Maher MM, Nassar MI: Acute cytomegalovirus infection is a risk factor in refractory and complicated inflammatory bowel disease. Dig Dis Sci 2009, 54: 2456-2462.

74. Criscuoli V, Mocciaro F, Orlando A, Rizzuto MR, Renda MC, Cottone M: Cytomegalovirus disappearance after treatment for refractory ulcerative colitis in 2 patients treated with infliximab and 1 patient with leukapheresis. Inflamm Bowel Dis 2009, 15: 810-811.

75. Matsuoka K, Iwao Y, Mori T, Sakuraba A, Yajima T, Hisamatsu T, Okamoto S, Morohoshi $Y$, Izumiya $M$, Ichikawa $H$, et al: Cytomegalovirus is frequently reactivated and disappears without antiviral agents in ulcerative colitis patients. Am J Gastroenterol 2007, 102: 331-337.

76. Leveque N, Brixi-Benmansour H, Reig T, Renois F, Talmud D, Brodard V, Coste JF, De Champs C, Andreoletti L, Diebold MD: Low frequency of cytomegalovirus infection during exacerbations of inflammatory bowel diseases. J Med Virol 2010, 82: 1694-1700.

77. Kishore J, Ghoshal U, Ghoshal UC, Krishnani N, Kumar S, Singh M, Ayyagari A: Infection with cytomegalovirus in patients with inflammatory bowel disease: prevalence, clinical significance and outcome. J Med Microbiol 2004, 53: 1155-1160.

78. Daniels JA, Lederman HM, Maitra A, Montgomery EA: Gastrointestinal tract pathology in patients with common variable immunodeficiency (CVID): a clinicopathologic study and review. Am J Surg Pathol 2007, 31: 1800-1812.

79. Raeiszadeh M, Kopycinski J, Paston SJ, Diss T, Lowdell M, Hardy GA Hislop AD, Workman S, Dodi A, Emery V, et al: The T cell response to persistent herpes virus infections in common variable immunodeficiency. Clin Exp Immunol 2006, 146: 234-242

80. Mandell BF, Calabrese LH: Infections and systemic vasculitis. Curr Opin Rheumatol 1998, 10: 51-57.

81. Mori T, Kameda H, Ogawa H, lizuka A, Sekiguchi N, Takei H, Nagasawa H, Tokuhira M, Tanaka T, Saito Y, et al: Incidence of cytomegalovirus reactivation in patients with inflammatory connective tissue diseases who are under immunosuppressive therapy. J Rheumatol 2004, 31: 1349-1351.

82. Lidar M, Lipschitz N, Langevitz P, Barzilai O, Ram M, Porat-Katz BS, Pagnoux C, Guilpain P, Sinico RA, Radice A, et al: Infectious serologies and autoantibodies in Wegener's granulomatosis and other vasculitides: novel associations disclosed using the Rad BioPlex 2200. Ann N Y Acad Sci 2009, 1173: 649-657.

83. Lunardi C, Bason C, Corrocher R, Puccetti A: Induction of endothelial cell damage by hCMV molecular mimicry. Trends Immunol 2005, 26: 19-24.

84. Namboodiri AM, Rocca KM, Pandey JP: IgG antibodies to human cytomegalovirus late protein UL94 in patients with systemic sclerosis. Autoimmunity 2004, 37: 241-244.

85. Lunardi C, Bason C, Navone R, Millo E, Damonte G, Corrocher R, Puccetti A: Systemic sclerosis immunoglobulin $G$ autoantibodies bind the human cytomegalovirus late protein UL94 and induce apoptosis in human endothelial cells. Nat Med 2000, 6: 1183-1186.

86. Lunardi C, Dolcino M, Peterlana D, Bason C, Navone R, Tamassia N, Beri R, Corrocher R, Puccetti A: Antibodies against human cytomegalovirus in the pathogenesis of systemic sclerosis: a gene array approach. PLoS Med 2006, 3: e2. 
87. Asadullah K, Prosch S, Audring H, Buttnerova I, Volk HD, Sterry W, Docke WD: A high prevalence of cytomegalovirus antigenaemia in patients with moderate to severe chronic plaque psoriasis: an association with systemic tumour necrosis factor alpha overexpression. Br J Dermatol 1999, 141: 94-102.

88. Einsele H, Steidle M, Muller CA, Fritz P, Zacher J, Schmidt H, Saal JG: Demonstration of cytomegalovirus (CMV) DNA and anti-CMV response in the synovial membrane and serum of patients with rheumatoid arthritis. J Rheumatol 1992, 19: 677-681.

89. Hamerman D, Gresser I, Smith C: Isolation of cytomegalovirus from synovial cells of a patient with rheumatoid arthritis. J Rheumatol 1982, 9 658-664.

90. Mehraein Y, Lennerz C, Ehlhardt S, Remberger K, Ojak A, Zang KD: Latent Epstein-Barr virus (EBV) infection and cytomegalovirus (CMV) infection in synovial tissue of autoimmune chronic arthritis determined by RNA- and DNA-in situ hybridization. Mod Pathol 2004, 17: 781-789.

91. Murayama T, Jisaki F, Ayata M, Sakamuro D, Hironaka T, Hirai K, Tsuchiya N, Ito K, Furukawa T: Cytomegalovirus genomes demonstrated by polymerase chain reaction in synovial fluid from rheumatoid arthritis patients. Clin Exp Rheumatol 1992, 10: 161-164.

92. Zhang C, Shen $K$, Jiang Z, He X: Early diagnosis and monitoring of active HCMV infection in children with systemic lupus erythematosus. Chin Med $J$ (Engl) 2001, 114: 1309-1312.

93. Nawata M, Seta N, Yamada M, Sekigawa I, Lida N, Hashimoto H: Possible triggering effect of cytomegalovirus infection on systemic lupus erythematosus. Scand J Rheumatol 2001, 30: 360-362.

94. Hayashi T, Lee S, Ogasawara H, Sekigawa I, lida N, Tomino Y, Hashimoto H, Hirose S: Exacerbation of systemic lupus erythematosus related to cytomegalovirus infection. Lupus 1998, 7: 561-564

95. Vasquez V, Barzaga RA, Cunha BA: Cytomegalovirus-induced flare of systemic lupus erythematosus. Heart Lung 1992, 21: 407-408.

96. Sekigawa I, Nawata M, Seta N, Yamada M, lida N, Hashimoto H: Cytomegalovirus infection in patients with systemic lupus erythematosus. Clin Exp Rheumatol 2002, 20: 559-564.

97. Cunha BA, Gouzhva O, Nausheen S: Severe cytomegalovirus (CMV) community-acquired pneumonia (CAP) precipitating a systemic lupus erythematosus (SLE) flare. Heart Lung 2009, 38: 249-252.

98. Su BY, Su CY, Yu SF, Chen CJ: Incidental discovery of high systemic lupus erythematosus disease activity associated with cytomegalovirus viral activity. Med Microbiol Immunol 2007, 196: 165-170.

99. Barzilai O, Sherer Y, Ram M, Izhaky D, Anaya JM, Shoenfeld Y: Epstein-Barr virus and cytomegalovirus in autoimmune diseases: are they truly notorious? A preliminary report. Ann N Y Acad Sci 2007, 1108: 567-577.

100. Chang M, Pan MR, Chen DY, Lan JL: Human cytomegalovirus pp65 lower matrix protein: a humoral immunogen for systemic lupus erythematosus patients and autoantibody accelerator for NZB/W F1 mice. Clin Exp Immunol 2006, 143: 167-179.

101. Berkun Y, Zandman-Goddard G, Barzilai O, Boaz M, Sherer Y, Larida B, Blank M, Anaya JM, Shoenfeld Y: Infectious antibodies in systemic lupus erythematosus patients. Lupus 2009, 18: 1129-1135.

102. Boeckh M, Nichols WG: Immunosuppressive effects of beta-herpesviruses. Herpes 2003, 10: 12-16.

103. George MJ, Snydman DR, Werner BG, Griffith J, Falagas ME, Dougherty NN, Rubin $\mathrm{RH}$ : The independent role of cytomegalovirus as a risk factor for invasive fungal disease in orthotopic liver transplant recipients. Boston Center for Liver Transplantation CMVIG-Study Group. Cytogam, Medlmmune, Inc. Gaithersburg, Maryland. Am J Med 1997, 103: 106-113.

104. Kalil AC, Levitsky J, Lyden E, Stoner J, Freifeld AG: Meta-analysis: the efficacy of strategies to prevent organ disease by cytomegalovirus in solid organ transplant recipients. Ann Intern Med 2005, 143: 870-880.

105. Hodson EM, Jones CA, Webster AC, Strippoli GF, Barclay PG, Kable K, Vimalachandra D, Craig JC: Antiviral medications to prevent cytomegalovirus disease and early death in recipients of solid-organ transplants: a systematic review of randomised controlled trials. Lancet 2005, 365: 2105-2115.

106. Razonable RR, Paya CV: The impact of human herpesvirus- 6 and -7 infection on the outcome of liver transplantation. Liver Transp/ 2002, 8: 651-658.

107. Razonable RR, Burak KW, van Cruijsen H, Brown RA, Charlton MR, Smith TF, Espy MJ, Kremers W, Wilson JA, Groettum C, et al: The pathogenesis of hepatitis C virus is influenced by cytomegalovirus. Clin Infect Dis 2002, 35: 974-981.

108. Franco A, Jimenez L, Sillero C, Trigueros M, Gonzalez D, Alcaraz E, Olivares J: [Post-transplant lymphoproliferative disorders in renal transplantation: two decades of experience]. Nefrologia 2010, 30: 669-675.

109. Walker RC, Marshall WF, Strickler JG, Wiesner RH, Velosa JA, Habermann TM, McGregor CG, Paya CV: Pretransplantation assessment of the risk of lymphoproliferative disorder. Clin Infect Dis 1995, 20: 1346-1353.

110. Manez R, Breinig MC, Linden P, Wilson J, Torre-Cisneros J, Kusne S, Dummer S, Ho M: Posttransplant lymphoproliferative disease in primary Epstein-Barr virus infection after liver transplantation: the role of cytomegalovirus disease. J Infect Dis 1997, 176: 1462-1467.

111. Kim JM, Lee SK, Kim SJ, Joh JW, Kwon CH, Choe YH, Shin M, Kim EY, Moon Jl, Jung GO, et al: Risk factors for posttransplant lymphoproliferative disorder in pediatric liver transplant recipients with cytomegalovirus antigenemia. Transplant Proc 2010, 42: 895-899.

112. Caillard S, Dharnidharka V, Agodoa L, Bohen E, Abbott K: Posttransplant lymphoproliferative disorders after renal transplantation in the United States in era of modern immunosuppression. Transplantation 2005, 80: 1233-1243.

113. Schubert $S$, Abdul-Khaliq $H$, Lehmkuhl HB, Yegitbasi M, Reinke $P$, Kebelmann-Betzig C, Hauptmann K, Gross-Wieltsch U, Hetzer R, Berger F: Diagnosis and treatment of post-transplantation lymphoproliferative disorder in pediatric heart transplant patients. Pediatr Transplant 2009, 13: 54-62.

114. Nichols WG, Corey L, Gooley T, Davis C, Boeckh M: High risk of death due to bacterial and fungal infection among cytomegalovirus (CMV)seronegative recipients of stem cell transplants from seropositive donors: evidence for indirect effects of primary CMV infection. J Infect Dis 2002, 185: 273-282.

115. Prentice $H G$, Gluckman E, Powles RL, Ljungman P, Milpied N, Fernandez Ranada JM, Mandelli F, Kho P, Kennedy L, Bell AR: Impact of long-term acyclovir on cytomegalovirus infection and survival after allogeneic bone marrow transplantation. European Acyclovir for CMV Prophylaxis Study Group. Lancet 1994, 343: 749-753.

116. Ljungman $\mathrm{P}$, Brand $\mathrm{R}$, Einsele $\mathrm{H}$, Frassoni $F$, Niederwieser $D$, Cordonnier $C$ : Donor CMV serologic status and outcome of CMV-seropositive recipients after unrelated donor stem cell transplantation: an EBMT megafile analysis. Blood 2003, 102: 4255-4260.

117. Boeckh M, Nichols WG: The impact of cytomegalovirus serostatus of donor and recipient before hematopoietic stem cell transplantation in the era of antiviral prophylaxis and preemptive therapy. Blood 2004, 103: 2003-2008.

118. Tong CY, Bakran A, Peiris JS, Muir P, Herrington CS: The association of viral infection and chronic allograft nephropathy with graft dysfunction after renal transplantation. Transplantation 2002, 74: 576-578.

119. Snyder LD, Finlen-Copeland CA, Turbyfill WJ, Howell D, Willner DA, Palmer SM: Cytomegalovirus pneumonitis is a risk for bronchiolitis obliterans syndrome in lung transplantation. Am J Respir Crit Care Med 181: 1391-1396.

120. Humar A, Gillingham K, Payne WD, Dunn DL, Sutherland DE, Matas AJ: Association between cytomegalovirus disease and chronic rejection in kidney transplant recipients. Transplantation 1999, 68: 1879-1883.

121. Falagas ME, Snydman DR, Griffith J, Ruthazer R, Werner BG: Effect of cytomegalovirus infection status on first-year mortality rates among orthotopic liver transplant recipients. The Boston Center for Liver Transplantation CMVIG Study Group. Ann Intern Med 1997, 126: 275-279.

122. Grattan MT, Moreno-Cabral CE, Starnes VA, Oyer PE, Stinson EB, Shumway NE: Cytomegalovirus infection is associated with cardiac allograft rejection and atherosclerosis. Jama 1989, 261: 3561-3566.

123. Hussain T, Burch M, Fenton MJ, Whitmore PM, Rees P, Elliott M, Aurora P: Positive pretransplantation cytomegalovirus serology is a risk factor for cardiac allograft vasculopathy in children. Circulation 2007, 115: 1798-1805.

124. Billingham ME: Histopathology of graft coronary disease. J Heart Lung Transplant 1992, 11: S38-44.

125. Weill D: Role of cytomegalovirus in cardiac allograft vasculopathy. Transp/ Infect Dis 2001, 3(Suppl 2): 44-48.

126. Wu TC, Hruban RH, Ambinder RF, Pizzorno M, Cameron DE, Baumgartner WA, Reitz BA, Hayward GS, Hutchins GM: Demonstration of 
cytomegalovirus nucleic acids in the coronary arteries of transplanted hearts. Am J Pathol 1992, 140: 739-747.

127. Tu W, Potena L, Stepick-Biek P, Liu L, Dionis KY, Luikart H, Fearon WF, Holmes TH, Chin C, Cooke JP, et al: T-cell immunity to subclinical cytomegalovirus infection reduces cardiac allograft disease. Circulation 2006, 114: 1608-1615.

128. Pouria S, State Ol, Wong W, Hendry BM: CMV infection is associated with transplant renal artery stenosis. Qjm 1998, 91: 185-189.

129. Chmiel C, Speich R, Hofer M, Michel D, Mertens T, Weder W, Boehler A: Ganciclovir/valganciclovir prophylaxis decreases cytomegalovirus-related events and bronchiolitis obliterans syndrome after lung transplantation. Clin Infect Dis 2008, 46: 831-839.

130. Lowance D, Neumayer HH, Legendre CM, Squifflet JP, Kovarik J, Brennan PJ, Norman D, Mendez R, Keating MR, Coggon GL, et al: Valacyclovir for the prevention of cytomegalovirus disease after renal transplantation. International Valacyclovir Cytomegalovirus Prophylaxis Transplantation Study Group. N Engl J Med 1999, 340: 1462-1470.

131. Valantine HA, Gao SZ, Menon SG, Renlund DG, Hunt SA, Oyer P, Stinson EB, Brown BW Jr, Merigan TC, Schroeder JS: Impact of prophylactic immediate posttransplant ganciclovir on development of transplant atherosclerosis: a post hoc analysis of a randomized, placebo-controlled study. Circulation 1999, 100: 61-66

132. Fiddian P, Sabin CA, Griffiths PD: Valacyclovir provides optimum acyclovir exposure for prevention of cytomegalovirus and related outcomes after organ transplantation. J Infect Dis 2002, 186(Suppl 1): S110-115.

133. Slifkin M, Ruthazer R, Freeman R, Bloom J, Fitzmaurice $S$, Fairchild $R$, Angelis M, Cooper J, Barefoot L, Rohrer R, et al: Impact of cytomegalovirus prophylaxis on rejection following orthotopic liver transplantation. Liver Transp/ 2005, 11: 1597-1602.

134. Miller W, Flynn P, McCullough J, Balfour HH Jr, Goldman A, Haake R, McGlave P, Ramsay N, Kersey J: Cytomegalovirus infection after bone marrow transplantation: an association with acute graft-v-host disease. Blood 1986, 67: 1162-1167.

135. Ljungman P, Perez-Bercoff L, Jonsson J, Avetisyan G, Sparrelid E, Aschan J, Barkholt L, Larsson K, Winiarski J, Yun Z, et al: Risk factors for the development of cytomegalovirus disease after allogeneic stem cell transplantation. Haematologica 2006, 91: 78-83.

136. Cantoni N, Hirsch HH, Khanna N, Gerull S, Buser A, Bucher C, Halter J, Heim D, Tichelli A, Gratwohl A, et al: Evidence for a bidirectional relationship between cytomegalovirus replication and acute graftversus-host disease. Biol Blood Marrow Transplant 2010, 16: 1309-1314.

137. Matthes-Martin S, Aberle SW, Peters C, Holter W, Popow-Kraupp T, Potschger U, Fritsch G, Ladenstein R, Rosenmayer A, Dieckmann K, et al: CMV-viraemia during allogenic bone marrow transplantation in paediatric patients: association with survival and graft-versus-host disease. Bone Marrow Transplant 1998, 21(Suppl 2): S53-56.

138. Wang LR, Dong $L$, Zhang MJ, Lu DP: Correlations of human herpesvirus $6 \mathrm{~B}$ and $\mathrm{CMV}$ infection with acute GVHD in recipients of allogeneic haematopoietic stem cell transplantation. Bone Marrow Transplant 2008, 42: 673-677.

139. Broers AE, van Der Holt R, van Esser JW, Gratama JW, Henzen-Logmans S, Kuenen-Boumeester V, Lowenberg B, Cornelissen JJ: Increased transplantrelated morbidity and mortality in CMV-seropositive patients despite highly effective prevention of CMV disease after allogeneic T-celldepleted stem cell transplantation. Blood 2000, 95: 2240-2245.

140. Lonnqvist B, Ringden O, Wahren B, Gahrton G, Lundgren G: Cytomegalovirus infection associated with and preceding chronic graftversus-host disease. Transplantation 1984, 38: 465-468.

141. Larsson K, Aschan J, Remberger M, Ringden O, Winiarski J, Ljungman P: Reduced risk for extensive chronic graft-versus-host disease in patients receiving transplants with human leukocyte antigen-identical sibling donors given polymerase chain reaction-based preemptive therapy against cytomegalovirus. Transplantation 2004, 77: 526-531.

142. Ljungman P, de La Camara R, Milpied N, Volin L, Russell CA, Crisp A, Webster A: Randomized study of valacyclovir as prophylaxis against cytomegalovirus reactivation in recipients of allogeneic bone marrow transplants. Blood 2002, 99: 3050-3056.

143. Michelson S: Consequences of human cytomegalovirus mimicry. Hum Immunol 2004, 65: 465-475.

144. Hutt-Fletcher LM, Balachandran N, Elkins MH: B cell activation by cytomegalovirus. J Exp Med 1983, 158: 2171-2176.
145. Varani S, Cederarv M, Feld S, Tammik C, Frascaroli G, Landini MP, Soderberg-Naucler C: Human cytomegalovirus differentially controls B cell and T cell responses through effects on plasmacytoid dendritic cells. J Immunol 2007, 179: 7767-7776.

146. Homs S, Mansour H, Desvaux D, Diet C, Hazan M, Buchler M, Lebranchu Y Buob D, Badoual C, Matignon M, et al: Predominant Th1 and cytotoxic phenotype in biopsies from renal transplant recipients with transplant glomerulopathy. Am J Transplant 2009, 9: 1230-1236.

147. Lamprecht $P$, Gross WL: Wegener's granulomatosis. Herz 2004, 29: 47-56.

148. Kobayashi T, Okamoto S, Iwakami Y, Nakazawa A, Hisamatsu T, Chinen H, Kamada N, Imai T, Goto H, Hibi T: Exclusive increase of CX3CR1+CD28CD4+ T cells in inflammatory bowel disease and their recruitment as intraepithelial lymphocytes. Inflamm Bowel Dis 2007, 13: 837-846.

149. Thewissen M, Linsen L, Somers V, Geusens P, Raus J, Stinissen P: Premature immunosenescence in rheumatoid arthritis and multiple sclerosis patients. Ann N Y Acad Sci 2005, 1051: 255-262.

150. Fasth AE, Dastmalchi M, Rahbar A, Salomonsson S, Pandya JM, Lindroos E, Nennesmo I, Malmberg KJ, Soderberg-Naucler C, Trollmo C, et al: T cell infiltrates in the muscles of patients with dermatomyositis and polymyositis are dominated by CD28null T cells. J Immunol 2009, 183 4792-4799.

151. Thewissen M, Somers V, Hellings N, Fraussen J, Damoiseaux J, Stinissen P: CD4+CD28null T cells in autoimmune disease: pathogenic features and decreased susceptibility to immunoregulation. J Immunol 2007, 179: 6514-6523.

152. Komocsi A, Lamprecht P, Csernok E, Mueller A, Holl-Ulrich K, Seitzer U, Moosig F, Schnabel A, Gross WL: Peripheral blood and granuloma CD4(+) CD28(-) T cells are a major source of interferon-gamma and tumor necrosis factor-alpha in Wegener's granulomatosis. Am J Pathol 2002, 160: 1717-1724

153. Gerli R, Schillaci G, Giordano A, Bocci EB, Bistoni O, Vaudo G, Marchesi S, Pirro M, Ragni F, Shoenfeld Y, et al: CD4+CD28- T lymphocytes contribute to early atherosclerotic damage in rheumatoid arthritis patients. Circulation 2004, 109: 2744-2748.

154. van Leeuwen EM, Remmerswaal EB, Vossen MT, Rowshani AT, Wertheimvan Dillen PM, van Lier RA, ten Berge IJ: Emergence of a CD4+CD28granzyme B+, cytomegalovirus-specific T cell subset after recovery of primary cytomegalovirus infection. J Immunol 2004, 173: 1834-1841.

155. Prosch S, Staak K, Stein J, Liebenthal C, Stamminger T, Volk HD, Kruger DH: Stimulation of the human cytomegalovirus IE enhancer/promoter in $\mathrm{HL}$ 60 cells by TNFalpha is mediated via induction of NF-kappaB. Virology 1995, 208: 197-206.

156. Zhu H, Cong JP, Yu D, Bresnahan WA, Shenk TE: Inhibition of cyclooxygenase 2 blocks human cytomegalovirus replication. Proc Natl Acad Sci USA 2002, 99: 3932-3937.

157. Qiu H, Straat K, Rahbar A, Wan M, Soderberg-Naucler C, Haeggstrom JZ: Human CMV infection induces 5-lipoxygenase expression and leukotriene B4 production in vascular smooth muscle cells. J Exp Med 2008, 205: 19-24

158. Sinzger C, Plachter B, Grefte A, The TH, Jahn G: Tissue macrophages are infected by human cytomegalovirus in vivo. J Infect Dis 1996, 173 240-245.

159. Riegler S, Hebart H, Einsele H, Brossart P, Jahn G, Sinzger C: Monocytederived dendritic cells are permissive to the complete replicative cycle of human cytomegalovirus. J Gen Virol 2000, 81: 393-399.

160. Frascaroli G, Varani S, Blankenhorn N, Pretsch R, Bacher M, Leng L, Bucala R, Landini MP, Mertens T: Human cytomegalovirus paralyzes macrophage motility through down-regulation of chemokine receptors, reorganization of the cytoskeleton, and release of macrophage migration inhibitory factor. J Immunol 2009, 182: 477-488.

161. Beck K, Meyer-Konig U, Weidmann M, Nern C, Hufert FT: Human cytomegalovirus impairs dendritic cell function: a novel mechanism of human cytomegalovirus immune escape. Eur I Immunol 2003, 33: 1528-1538.

162. Varani S, Frascaroli G, Homman-Loudiyi M, Feld S, Landini MP, SoderbergNaucler C: Human cytomegalovirus inhibits the migration of immature dendritic cells by down-regulating cell-surface CCR1 and CCR5. I Leukoc Biol 2005, 77: 219-228.

163. Somer T, Finegold SM: Vasculitides associated with infections, immunization, and antimicrobial drugs. Clin Infect Dis 1995, 20: 1010-1036. 
164. Rodriguez-Pla A, Stone JH: Vasculitis and systemic infections. Curr Opin Rheumatol 2006, 18: 39-47

165. Streblow DN, Orloff SL, Nelson JA: Acceleration of allograft failure by cytomegalovirus. Curr Opin Immunol 2007, 19: 577-582.

166. Kahl M, Siegel-Axel D, Stenglein S, Jahn G, Sinzger C: Efficient lytic infection of human arterial endothelial cells by human cytomegalovirus strains. J Virol 2000, 74: 7628-7635.

167. Ho DD, Rota TR, Andrews CA, Hirsch MS: Replication of human cytomegalovirus in endothelial cells. J Infect Dis 1984, 150: 956-957.

168. Fish KN, Soderberg-Naucler C, Mills LK, Stenglein S, Nelson JA: Human cytomegalovirus persistently infects aortic endothelial cells. J Virol 1998, 72: 5661-5668.

169. Shen YH, Zhang L, Utama B, Wang J, Gan Y, Wang X, Wang J, Chen L, Vercellotti GM, Coselli JS, et al: Human cytomegalovirus inhibits Aktmediated eNOS activation through upregulating PTEN (phosphatase and tensin homolog deleted on chromosome 10). Cardiovasc Res 2006, 69 : 502-511.

170. Craigen $\mathrm{J}$, Yong $\mathrm{KL}$, Jordan NJ, MacCormac LP, Westwick J, Akbar AN Grundy JE: Human cytomegalovirus infection up-regulates interleukin-8 gene expression and stimulates neutrophil transendothelial migration. Immunology 1997, 92: 138-145.

171. Dengler TJ, Raftery MJ, Werle M, Zimmermann R, Schonrich G: Cytomegalovirus infection of vascular cells induces expression of proinflammatory adhesion molecules by paracrine action of secreted interleukin-1 beta. Transplantation 2000, 69: 1160-1168.

172. Bolovan-Fritts CA, Trout RN, Spector SA: Human cytomegalovirus-specific CD4+-T-cell cytokine response induces fractalkine in endothelial cells. J Virol 2004, 78: 13173-13181.

173. Bolovan-Fritts CA, Spector SA: Endothelial damage from cytomegalovirusspecific host immune response can be prevented by targeted disruption of fractalkine-CX3CR1 interaction. Blood 2008, 111: 175-182.

174. Van Dam-Mieras MC, Bruggeman CA, Muller AD, Debie WH, Zwaal RF: Induction of endothelial cell procoagulant activity by cytomegalovirus infection. Thromb Res 1987, 47: 69-75.

175. Rahbar A, Soderberg-Naucler C: Human cytomegalovirus infection of endothelial cells triggers platelet adhesion and aggregation. J Virol 2005, 79: 2211-2220.

176. Goldmacher VS: Cell death suppression by cytomegaloviruses. Apoptosis 2005, 10: 251-265.

177. Zhou YF, Yu ZX, Wanishsawad C, Shou M, Epstein SE: The immediate early gene products of human cytomegalovirus increase vascular smooth muscle cell migration, proliferation, and expression of PDGF betareceptor. Biochem Biophys Res Commun 1999, 256: 608-613

178. Streblow DN, Soderberg-Naucler C, Vieira J, Smith P, Wakabayashi E, Ruchti F, Mattison K, Altschuler Y, Nelson JA: The human cytomegalovirus chemokine receptor US28 mediates vascular smooth muscle cell migration. Cell 1999, 99: 511-520.

179. Dumortier J, Streblow DN, Moses AV, Jacobs JM, Kreklywich CN, Camp D, Smith RD, Orloff SL, Nelson JA: Human cytomegalovirus secretome contains factors that induce angiogenesis and wound healing. I Virol 2008, 82: 6524-6535.

180. Looney RJ, Falsey A, Campbell D, Torres A, Kolassa J, Brower C, McCann R, Menegus M, McCormick K, Frampton M, et al: Role of cytomegalovirus in the T cell changes seen in elderly individuals. Clin Immunol 1999, 90: 213-219.

181. Naniche D, Oldstone MB: Generalized immunosuppression: how viruses undermine the immune response. Cell Mol Life Sci 2000, 57: 1399-1407.

182. Griffin D: Potential mechanisms of immune suppression. In Viral Pathogenesis. Edited by: Nathanson N. Lippincott-Raven; 1996: 207-235.

183. Rinaldo CR Jr, Carney WP, Richter BS, Black PH, Hirsch MS: Mechanisms of immunosuppression in cytomegaloviral mononucleosis. J Infect Dis 1980, 141: 488-495.

184. Levin MJ, Rinaldo CR Jr, Leary PL, Zaia JA, Hirsch MS: Immune response to herpesvirus antigens in adults with acute cytomegaloviral mononucleosis. J Infect Dis 1979, 140: 851-857.

185. Reynolds DW, Dean PH, Pass RF, Alford CA: Specific cell-mediated immunity in children with congenital and neonatal cytomegalovirus infection and their mothers. J Infect Dis 1979, 140: 493-499.

186. Fiorilli M, Sirianni MC, lannetti P, Pana A, Divizia M, Aiuti F: Cell-mediated immunity in human cytomegalovirus infection. Infect Immun 1982, 35: 1162-1164.
187. Kapasi K, Rice GP: Role of the monocyte in cytomegalovirus-mediated immunosuppression in vitro. J Infect Dis 1986, 154: 881-884.

188. Schrier RD, Oldstone MB: Recent clinical isolates of cytomegalovirus suppress human cytomegalovirus-specific human leukocyte antigenrestricted cytotoxic T-lymphocyte activity. J Virol 1986, 59: 127-131.

189. Schrier RD, Rice GP, Oldstone MB: Suppression of natural killer cell activity and $\mathrm{T}$ cell proliferation by fresh isolates of human cytomegalovirus. J Infect Dis 1986, 153: 1084-1091.

190. Simmons P, Kaushansky K, Torok-Storb B: Mechanisms of cytomegalovirusmediated myelosuppression: perturbation of stromal cell function versus direct infection of myeloid cells. Proc Natl Acad Sci USA 1990, 87: 1386-1390.

191. Torok-Storb B, Simmons P, Khaira D, Stachel D, Myerson D: Cytomegalovirus and marrow function. Ann Hematol 1992, 64(Suppl): A128-131.

192. Randolph-Habecker J, Iwata M, Torok-Storb B: Cytomegalovirus mediated myelosuppression. J Clin Virol 2002, 25(Suppl 2): S51-56.

193. Frascaroli G, Varani S, Moepps B, Sinzger C, Landini MP, Mertens T: Human cytomegalovirus subverts the functions of monocytes, impairing chemokine-mediated migration and leukocyte recruitment. J Virol 2006, 80: $7578-7589$

194. Gredmark S, Soderberg-Naucler C: Human cytomegalovirus inhibits differentiation of monocytes into dendritic cells with the consequence of depressed immunological functions. J Virol 2003, 77: 10943-10956.

195. Gredmark S, Tilburgs T, Soderberg-Naucler C: Human cytomegalovirus inhibits cytokine-induced macrophage differentiation. J Virol 2004, 78: 10378-10389.

196. Hertel L, Lacaille VG, Strobl H, Mellins ED, Mocarski ES: Susceptibility of immature and mature Langerhans cell-type dendritic cells to infection and immunomodulation by human cytomegalovirus. J Virol 2003, 77 : 7563-7574.

197. Lee AW, Hertel L, Louie RK, Burster T, Lacaille V, Pashine A, Abate DA, Mocarski ES, Mellins ED: Human cytomegalovirus alters localization of MHC class II and dendrite morphology in mature Langerhans cells. J Immunol 2006, 177: 3960-3971.

198. Moutaftsi M, Brennan P, Spector SA, Tabi Z: Impaired lymphoid chemokine-mediated migration due to a block on the chemokine receptor switch in human cytomegalovirus-infected dendritic cells. J Virol 2004, 78: 3046-3054.

199. Moutaftsi M, Mehl AM, Borysiewicz LK, Tabi Z: Human cytomegalovirus inhibits maturation and impairs function of monocyte-derived dendritic cells. Blood 2002, 99: 2913-2921.

200. Chang WL, Baumgarth N, Yu D, Barry PA: Human cytomegalovirusencoded interleukin-10 homolog inhibits maturation of dendritic cells and alters their functionality. J Virol 2004, 78: 8720-8731.

201. Raftery MJ, Wieland D, Gronewald S, Kraus AA, Giese T, Schonrich G: Shaping phenotype, function, and survival of dendritic cells by cytomegalovirus-encoded IL-10. J Immunol 2004, 173: 3383-3391.

202. Razonable RR: Immune-based therapies for cytomegalovirus infection. Immunotherapy 2010, 2: 117-130.

203. Lux A, Aschermann S, Biburger M, Nimmerjahn F: The pro and antiinflammatory activities of immunoglobulin G. Ann Rheum Dis 2010, 69(Suppl 1): i92-96.

204. Lawlor G, Moss AC: Cytomegalovirus in inflammatory bowel disease: pathogen or innocent bystander? Inflamm Bowel Dis 2010, 16: 1620-1627.

205. Nakase H, Chiba T: TNF-alpha is an important pathogenic factor contributing to reactivation of cytomegalovirus in inflamed mucosa of colon in patients with ulcerative colitis: lesson from clinical experience. Inflamm Bowel Dis 2010, 16: 550-551.

206. Soderberg-Naucler C: HCMV microinfections in inflammatory diseases and cancer. J Clin Virol 2008, 41: 218-223.

doi:10.1186/2042-4280-2-6

Cite this article as: Varani and Landini: Cytomegalovirus-induced immunopathology and its clinical consequences. Herpesviridae 2011 2:6. 